\title{
SERVICE EXCELLENT BAGI FINTECH SYARIAH DI TENGAH KONDISI COVID-19
}

\author{
Trimulato, Asyraf Mustamin, dan Ismawati ${ }^{1}$
}

\section{Abstrak}

Telah hadir financial Technologhy (fintech syariah) akses keuangan dengan memafaatkan teknologi, sesuai prinsip syariah. Fintech syariah masih terbilang baru, sehingga peluang untuk dapat berkembang masih terbuka. Adanya wabah covid-19 memberikan dampak kurang baik bagi fintech syariah khususnya fintech syariah peer to peer lending (P2P). Tujuan dari penelitian ini untuk mengetahui perkembangan fintech syariah dan untuk mengetahui pola service excellent fintech syariah di tengah wabah covid-19. Jenis penelitian ini adalah studi pustaka dengan sifat penelitian kualitatif. Teknik pengumpulan data penelitian ini menggunakan data sekunder telah ada sebelumnya, dari berbagai sumber yang dianggap sesuai tema penelitian. Teknik analisis data yang digunakan deksriptif kualitatif, menggambarkan hasil analisis dari data diperoleh terkait perkembangan fintech syariah dan service excellen untuk fintech syariah. Hasil penelitian menunjukkan bahwa asset fintech syariah jenis fintech lending syariah pada periode april sebesar 50,591,727,786, atau mengalami penurunan sebesar 0,05 persen. Jumlah pelaku fintech syariah $(P 2 P)$ sebanyak 12 perusahaan. Bentuk service excellent yang dilakukan fintech syariah di tengah wabah covid-19 yaitu meningkatakan penawaran menarik dan promo-promo yang dapat meningkatkan investor atau pihak pendana. Kemudian memperkuat silaturahim, memberi nasehat, serta membantu memasarkan produk-produk nasabah penerima dana. Bentuk service excellent fintech syariah di tengah wabah covid-19 berbeda dengan kondisi normal sebelum adanya virus covid-19.

Kata Kunci: Service Excellent, Fintech Syariah, dan Virus Covid-19

\section{Abstract}

Financial technology has been present, by providing access finance utilizing technology, with sharia principles. Sharia fintech still relatively new, so opportunity develop still open. Only at this time it is a little sluggish because the covid-19 has had a negative impact on sharia fintech, especially product peer to peer lending (P2P). Purpose this study is to determine development of sharia fintech and pattern service excellent for sharia fintech in midst of Covid-19. Type of research literature study with qualitative. Data collection use secondary data has been there before, from various sources are considered in accordance with research theme. Data analysis technique used descriptive qualitative, describing

1,2,3 Jurusan Perbankan Syariah Universitas Islam Negeri Alauddin Makassar Email: trimsiuii@yahoo.co.id, asyraf-mustamin@uin.ac.id 
results of analysis from data obtained related development sharia fintech and service excellence for sharia fintech. Results showed type of sharia fintech lending in April period were 50,591,727,786, or decreased by 0.05 percent. Number players (P2P) 12 companies. Form service excellent carried out by sharia fintech in midst Covid-19 outbreak is increasing attractive offers and promos can increase investors or lenders. Strengthen friendship, provide advice, and help market products for customers who receive funds. The service excellent of sharia fintech service in the midst covid-19 outbreak is different from normal conditions before covid-19 Pandemic.

Keywords: Excellent Service, Sharia Fintech, and during COVID-19 Pandemic

\section{A. PENDAHULUAN}

Teknologi Finansial adalah bisnis yang berfokus pada penyedia gagasan jasa finansial yang menggunakan perangkat lunak dan modern. Seiring perkembangan fintech saat ini, maka penerapannya dalam fiqh muamalah menurut perspektif Islam harus sesuai dengan prinsipprinsip syariah, yang terhindar dari Maysir, Gharar dan Riba. Selain itu, meskipun kegiatan tersebut menggunakan sistem teknologi maka prinsip-prinsip hukum ekonomi Islam harus tetap ditegakkan. Untuk itu penelitian terhadap akad akad tijarah dalam transaksi fintech dengan pendekata maqashid syariah ini harus dilakukan sehingga umat muslim dapat mengikuti perkembangan teknologi dan menggunakannya dengan tersedianya lembaga keuangan berbasis fintech yang mana dalam transaksinya sesuai dengan maqashid syariah (Yarli, 2018).

Pelaksanaan fintech Syariah di Indonesia pun mulai mendapat perhatian dari pemerintah dengan dikeluarkannya Fatwa berkaitan dengan Fintech Syariah oleh Dewan Syariah Nasional Majelis Ulama Indonesia (DSN-MUI) Nomor 117/DSN-MUI/II/2018 tentang Layanan Pembiayaan Berbasis Teknologi Informasi berdasarkan Prinsip Syariah. Namun sayangnya pendahulu dari fintech syariah yakni fintech konvensional memberikan citra yang kurang baik dengan munculnya pemberitaan dan stigma negatif tentang pelaksanaan fintech yang terjadi di masyarakat. Beberapa demo bahkan kasus bunuh diri terjadi di masyarakat dikarenakan fintech yang berbentuk pinjaman online yang menjerat kalangan masyarakat menengah kebawah. Kehadiran fintech syariah yang berlandaskan pada prinsip syariah diharapkan mampu memperbaiki tujuan awal dari kehadiran fintech yang seharusnya memudahkan masyarakat dalam melaksanakan kegiatan dan transaksi ekonomi yang berlandaskan prinsip syariah. Peluang dan

SERVICE EXCELLENT BAGI FINTECH SYARIAH

14

DI TENGAH KONDISI COVID-19

Trimulato, Asyraf Mustamin, dan Ismawati 
tantangan fintech syariah di Indonesia menjadi penting untuk dipelajari seiring dengan perkembangan pesat fintech syariah di Indonesia (Hiyanti et al., 2020).

Untuk meningkatkan eksistensi perbankan syariah lebih dapat berkompetitif pada pasar keuangan dan juga membantu proses percepatan pembiayaan di bank syariah dengan aplikasi yang lebih mudah, efisien, dan efektif dengan akses yang lebih luas lagi oleh nasabah dan bank syariah. Proses pembiayaan lebih cepat dan terukur dengan mitigasi risiko yang dapat dilakukan secara awal dengan sistem fintech. perhatian perbankan syariah terhadap peluang-peluang yang diperoleh dari penggunaan fintech tersebut merupakan hal yang begitu penting untuk memperluas pasar perbankan syariah, dimana kesempatan tersebut didukung dari produk-produk perbankan syariah yang dapat memenuhi segala kebutuhan masyarakat (Muchlis, 2018).

Dengan berbagai kelebihan tersebut, diharapkan seluruh pelaksanaan pembayaran dana dapat berlangsung atau dilaksanakan dengan menggunkan system perbankan. Dalam perkembangan muncul berbagai layanan jasa pinjam meminjam uang dengan berbasis pada teknologi informasi, yang tentunya menawarkan berbagai macam kemudahan. Berbagai kemudahan tersebut dipergunakan membantu memfasilitasi kebutuhan antara peminjam dana dan pemberi pinjaman. Selain Layanan Fintech secara Konvensional Terdapat pula layanan. Layanan fintech berbasis syariah, selain memberikan penawaran dan skema yang berbeda dari layanan yang sudah ada (konvensional), juga memberikan pembatasan pembatasan tertentu terhadap penggunaan dana yang diberikan oleh investor atau pemberi pinjaman. Kenyamanan yang diberikan atas transaksi melalui fintech berbasis syariah tidak lepas dari karakteristik bisnis syariah yang bersandar kepada pondasi ekonomi syariah yaitu ketuhanan (ila>hiyyah), keadilan (al-'adl), kenabian (al-nubu>wwah), pemerintahan (al-khali>fah), dan hasil $\left(a l-m a^{\prime} a>d\right)$. Permintaan pengguna jasa layanan fintech berbasis syariah yang meningkat yang di dukung dengan pangsa pasar pengguna layanan dari masyarakat Indonesia yang mayoritas muslim mendorong Layanan Fintech berbasis syariah wajib memenuhi kaidah kaidah dalam transaksi bisnis secara syariah (Alwi, 2018).

Otoritas Jasa Keuangan sebagai regulator industri keuangan telah mengeluarkan legal standing untuk industri fintech. Payung 
hukumnya adalah dalam bentuk Peraturan OJK Nomor 77/POJK.01/2016 tentang Layanan Pinjaman Kepemilikan Peer-to-Peer Lending/P2P Lending yang diterbitkan pada akhir Desember 2016. Namun, peraturan tersebut hanya mengatur fintech dengan sistem konvensional dan belum mengatur sistem syariah yang saat ini juga mulai tumbuh. Perusahaan fintech dapat diklasifikasikan sebagai: a) teknologi informasi dan perusahaan perangkat lunak yang mendukung dan memfasilitasi perusahaan sektor keuangan atau lebih disebut sebagai penyedia layanan teknologi bank dan b) tech-startups atau perusahaan inovatif kecil yang menggantikan perantara keuangan biasa, dengan kemudahan aksesibilitas yang mampu menyebabkan 'gangguan' bagi bank umum dan sistem perbankan (Rusydiana, 2019).

Regulasi mengenai Financial teknologi syariah ini harus didukung oleh OJK dengan peraturan Otoritas Jasa Keuangan Nomor 77/PJOK01/2016 tentang Layanan Pinjam Meminjam Uang Berbasis Teknologi Informasi. Namun regulasi ini lebih ke arah konvensional karena menggunakan istilah bunga (namun sudah berprinsip kebebasan berdemokrasi dan berkontrak) yang tidak sesuai dengan prinsip syariah. Fintech Peer to Peer Lending sudah diakui keberadaannya sejak POJK 77 Desember 2016 kemarin dan merupakan jenis yang off balance sheet, sehingga sulit untuk menilai/menentukan mana fintech syariah sehat atau yang tidak sehat. Penyelenggara P2P Lending harus memperhatikan aturan POJK 772016 tentang batas maksimal kepemilikan saham asing, modal minimum, batas maksimal pinjaman dan pembuatan secrow account. Penyelenggaraan transaksi keuangan juga diatur pada Peraturan Bank Indonesia Nomor 18/4/2016/BI tentang penyelenggaraan pemrosesan transaksi pembayaran yang mencakup perizinan, penyelenggaraan dan larangan (Setyaningsih, 2018).

Fintech syariah sebagai lembaga yang dibilang baru juga terkena dampak virus corona dalam kegiatannya. Teknologi tampaknya telah memobilisasi banyak perubahan dalam ekonomi dan masyarakat global, termasuk teknologi keuangan yang telah mengubah sistem dan proses dari berbagai bidang mulai dari pembayaran, pinjaman, urusan perbankan, manajemen aset, deteksi penipuan hingga tahap peraturan dan pendidikan keuangan jarak jauh. Ketika diberlakukannya Study From Home (SFH) dan Working From Home (WFH) saat pandemi Covid19 , semakin banyak masyarakat yang menggunakan teknologi internet

SERVICE EXCELLENT BAGI FINTECH SYARIAH

16

DI TENGAH KONDISI COVID-19

Trimulato, Asyraf Mustamin, dan Ismawati 
dengan tujuan pendidikan, berdakwah, penyelesaian pekerjaan atau hiburan. Hal ini harusnya memberikan dampak kepada kegiatan FinTech syariah yang perlu membantu memulihkan terpuruknya Usaha Mikro, Kecil dan Menengah (UMKM) saat ini. Momentum bagi Fintech syariah adalah saat tepat untuk mengajak masyarakat dan pembuat kebijakan menelaah lebih jauh tentang aspek syariah di bidang FinTech, mulai dari aqad, syarat dan ketentuan, serta harmonisasi dengan hukum, administrasi pajak, akuntansi dan audit. Kondisi aqad sangat penting, setiapnya harus memiliki objek yang mendasari ('aqid), subjek (mau'qud'alaihi), keinginan untuk melakukan aqad (sighat), dan pilar yang harus diungkapkan adalah harga, upah dan tunjangan. Kepatuhan dengan ketentuan hukum harus dicerminkan misalnya dalam bentuk tindakan, fatwa, sertifikasi syariah, termasuk akuntansi syariah untuk melaporkan transaksi. Jika saat ini semua FinTech syariah sudah siap maka setelah pandemi berakhir, FinTech syariah dapat tampil di garda depan sebagai tulang punggung perubahan ekonomi masyarakat dengan akad - akadnya yang syarat dengan nilai keadilan (Mukhlisin, 2020).

Asosiasi Fintech Syariah Indonesia (AFSI) menargetkan perusahaan fintech syariah bisa menyalurkan pembiayaan sebesar $\mathrm{Rp}$ 4,6 triliun di 2020. Namun, dengan adanya wabah virus corona, target pembiayaan fintech syariah di tahun ini bakal lebih rendah. Ketua Umum AFSI Ronald Yusuf Wijaya mengatakan, karena wabah corona tak sedikit industri yang mengalami penurunan skala bisnis dengan rentang penurunan $60 \%-100 \%$, tergantung pada jenis usaha. Terdapat beberapa sub sektor industri yang terdampak situasi ekonomi yang menurun akibat wabah virus corona. Misal resto, hotel dan travel yang terdampak paling besar. "Namun beberapa industri masih bisa menjadi andalan untuk pergerakan fintech syariah. Misal pertanian, peternakan, bahan dasar atau kebutuhan pokok juga segala jenis usaha yang terkatit dengan kebutuhan di bidang kesehatan," Perusahaan yang bergerak dalam jasa pengangkutan barang (freight forwarding) juga bisa dilirik pelaku fintech syariah. "AFSI memprediksi situasi ekonomi tidak berubah signifikan sampai dengan datangnya Idul Fitri. Ekonomi akan kembali pulih jika pemerintah maupun masyarakat berhasil menahan laju penyebaran virus corona," kata Ronald (Wijaya, 2020b). 
Perusahaan financial technology (fintech) berbasis syariah masih memiliki sejumlah kendala dalam berkembang. Beberapa diantaranya adalah kelengkapan infrastruktur pendukung dan literasi masyarakat. Ketua Asosiasi_Fintech Syariah_Indonesia (AFSI), Ronald Yusuf Wijaya menyampaikan peningkatan kapasitas dan infrastruktur pendukung industri akan menjadi fokus tahun ini. Tujuannya, demi mendongkrak pertumbuhan bisnis yang ditargetkan mencapai lima kali lipat. "Target kami tahun ini memperbaiki semua infrastruktur untuk mendorong fintech syariah karena memang ini kita alami banget," katanya di Jakarta. Sejumlah fintech syariah mengalami gap teknologi pada saat pendaftaran ke Otoritas Jasa Keuangan (OJK). Ia optimistis setelah infrastruktur rapi maka akan ada banyak fintech syariah yang mendapat dana segar dari venture capital. Selain itu, tingkat literasi yang rendah juga masih menjadi tantangan pertumbuhan fintech syariah (Wijaya, 2020a).

Dari uraian diatas peneliti merasa tertarik untuk melakukan penelitian lebih dalam terkait fintech syariah di tengah wabah covid-19, khususnya dalam memberikan pelayanan yang prima bagi konsumen. Adapun tujuan dari penelitian ini yaitu untuk mengetahui perkembangan fintech syariah dan untuk mengetahui pola service excellent untuk fintech syariah.

\section{B. STUDI PUSTAKA}

\section{Fintech Syariah}

Keuangan syariah adalah suatu sistem keuangan yang pelaksanaannya berdasarkan hukum Islam (syariah). Pembentukan sistem ini berdasarkan adanya larangan dalam agama Islam untuk meminjamkan atau memungut pinjaman dengan mengenakan bunga pinjaman (riba), serta larangan untuk berinvestasi pada usaha-usaha berkategori terlarang (haram), yang tidak dapat dijamin oleh system konvensional. Fintech merupakan salah satu bisnis berbasis software dan teknologi modern yang menyediakan jasa keuangan. Perusahaan fintech pada umumnya adalah perusahaan start-up yang memberikan layanan dan solusi keuangan kepada pelanggan seperti pembayaran mobile, transfer uang, pinjaman, penggalangan dana, dan bahkan manajemen aset. Fintech Syariah berarti layanan dan solusi keuangan yang diberikan perusahaan teknologi/startup fintech, yang berbasis hukumhukum Islam/syariah (Fintech, 2017). 
Teknologi digital merupakan terobosan serta inovasi baru dalam seluruh kegiatan ekonomi. Hal tersebut dapat mempengaruhi sektor perdagangan, pertanian dan secara khusus pada sektor keuangan. Salah satu sektor yang saat ini dikembangkan yaitu finansial technology atau lebih dikenal dengan istilah fintech yang menjadi inovasi terbaru masa kini. Pengertian Fintech Syariah menurut Mukhlisin dalam Dodi (2018) adalah kombinasi, inovasi yang ada dalam bidang keuangan dan teknologi yang memudahkan proses transaksi dan investasi berdasarkan nilainilai syariah. Ia berpendapat, walaupun fintech ini merupakan terobosan baru tetapi mengalami perkembangan yang pesat. Islam merupakan agama yang komprehensif sehingga dalam bidang keuangan ini harus memiliki aturan yang sesuai dengan prinsipnya sesuai syariah (Yarli, 2018).

Fintech merupakan kependekan dari financial technology (teknologi finansial). Fintech merupakan istilah yang populer dalam beberapa tahun terakhir ini. Ketika seseorang mendengar istilah fintech, maka yang terlintas dalam pikirannya adalah segala kemudahan dan kecepatan dalam transaksi keuangan, seperti kemudahan dan kecepatan dalam pembayaran, peminjaman, pengiriman, dan sebagainya. Dengan fintech diharapkan dapat menghemat waktu, pikiran, tenaga, dan biaya. Pada hakikatnya, fintech adalah layanan keuangan berbasis teknologi. Pembayaran tagihan listrik, cicilan kendaraan, atau premi asuransi secara online adalah beberapa contoh produk fintech yang sering digunakan dalam keseharian, demikian juga dengan pengiriman uang atau pengecekan saldo melalui online banking (Fahlefi, 2018).

Keberadaan Fintech yang semakin berkembang sehingga muncul Fintech yang berasaskan Syariah serta memudahkan nasabah tentu saja akan berpengaruh terhadap industri keuangan syariah formal seperti Bank Syariah, BPR Syariah, BMT dan industri keuangan syariah formal lainnya dimana transaksi pada industri keuangan syariah formal masih banyak menggunakan bukti fisik dalam transaksinya dan belum banyak menggunakan kemajuan teknologi yang semakin berkembang. Hal ini akan menjadikan industri keuangan formal menjadi kurang efektif karena biaya dan waktu yang dihabiskan akan lebih banyak. Jika industri keuangan syariah tidak mampu berinovasi dan memanfaatkan teknologi, maka akan tertinggal jauh oleh industri keuangan yang telah 
mengeluarkan Fintech yang perkembangannya sangat cepat. Dalam hal ini terdapat dampak Fintech terhadap industri keuangan syariah. Maka dari itu, dalam penelitian ini akan dibahas mengenai apakah ada dampak Fintech terhadap Industri Keuangan Syariah. Menurut Hsueh dalam Ansori (2019), Terdapat tiga tipe financial technology adalah sebagai berikut (Ansori, 2019):

1. Sistem pembayaran melalui pihak ketiga (Third-party payment systems), Contoh - contoh sistem pembayaran melalui pihak ketiga yaitu crossborderEC, online-to-offline $(\mathrm{O} 2 \mathrm{O})$, sistem pembayaran mobile, dan platform pembayaran yang menyediakan jasa seperti pembayaran bank dan transfer.

2. Peer-to-Peer (P2P) Lending. Peer-to-Peer Lending merupakan platform yang mempertemukan pemberi pinjaman dan peminjam melalui internet. Peer-to-Peer Lending menyediakan mekanisme kredit dan manajemen risiko. Platform ini membantu pemberi pinjaman dan peminjam memenuhi kebutuhan masing-masing dan menghasilkan penggunaan uang secara efisien. Peer-to-Peer Lending memiliki biaya lebih rendah dan efisiensi yang lebih tinggi daripada pinjaman berbasis bank tradisional. Dari beberapa pengertian tentang Peer-to-Peer Lending maka dapat diambil kesimpulan bahwa Peer-to-Peer Lending merupakan model bisnis keuangan yang mempertemukan antara pemberi pinjaman dan peminjam melalui sebuah platform dimana model ini lebih menguntungkan dibanding platform keuangan tradisional.

3. Crowdfunding, Crowdfunding merupakan tipe Fintech di mana sebuah konsep atau produk seperti desain, program, konten, dan karya kreatif dipublikasikan secara umum dan bagi masyarakat yang tertarik dan ingin mendukung konsep atau produk tersebut dapat memberikan dukungan secara finansial. Crowdfunding dapat digunakan untuk mengurangi kebutuhan finansial kewirausahaan, dan memprediksi permintaan pasar.

Kolaborasi financial technology dengan lembaga keuangan syariah, khususnya perbankan syariah dapat meningkatkan keuangan inklusif pada perbankan syariah di Indonesia. Hal tersebut dapat terjadi karena saat ini perkembangan teknologi sangat pesat dan telah masuk ke semua sektor, salah satunya yaitu sektor keuangan. Maka, dengan masuknya teknologi ke sektor keuangan akan mengubah industri keuangan ke era digital. Implementasi Fintech pada industri perbankan

\section{SERVICE EXCELLENT BAGI FINTECH SYARIAH}

20

DI TENGAH KONDISI COVID-19

Trimulato, Asyraf Mustamin, dan Ismawati 
syariah akan memudahkan dan mendekatkan pelaku bisnis, khususnya perbankan syariah untuk mengakses produkproduk layanan keuangan syariah yang ditawarkan dan mengajukan pembiayaan secara langsung tanpa harus datang langsung ke kantor-kantor cabang. Model seperti itu, selain mempermudah pelaku bisnis sektor perbankan syariah dalam mendapatkan akses keuangan, juga dapat meningkatkan keuangan inklusif serta dapat meningkatkan kinerja Bank Syariah (Sadari \& Hakim, 2016).

Peraturan Bank Indonesia Nomor 19/12/PBI/2017 tentang penyelenggaraan teknologi finansial menegaskan pengertian teknologi finansial (financial technology) sebagai penggunaan teknologi dalam sistem keuangan yang menghasilkan produk, layanan, teknologi, dan/atau model bisnis baru serta dapat berdampak pada stabilitas moneter, sistem keuangan, dan/atau efisiensi, kelancaran, keamanan, dan keandalan sistem pembayaran. Teknologi finansial (fintech) yang dimaksudkan adalah yang termasuk dalam sistem pembayaran, pendukung pasar, manajemen investasi dan manajemen risiko, pinjaman, pembiayaan, penyediaan modal, dan jasa finansial lainnya. Fintech peer-to-peer lending tergolong aktivitas pembaruan proses bisnis, model bisnis, dan instrument keuangan yang memberikan nilai ambah baru di sektor jasa keuangan dengan melibatkan ekosistem digital yang dikenal dengan istilah inovasi keuangan digital (IKD) (Baihaqi, 2018).

Fintech peer-to-peer lending berdasarkan prinsip syariah merupakan penyelenggaraan layana jasa keuangan berdasarkan prinsip syariah yang mempertemukan atau menghubungkan pemberi pembiayaan dengan penerima pembiayaan dalam rangka melakukan akad pembiayaan melalui sistem elektronik dengan menggunakan jaringan internet. Konsep fintech peer-to-peer lending berdasarkan prinsip syariah merupakan konsep penyelenggaraan layanan pembiayaan berbasis teknologi dengan tujuan untuk menghindari praktik yang dilarang oleh hukum Islam. Hal ini memberikan media bagi para pelaku kegiatan pembiayaan melalui penyelenggara fintech untuk melaksanaan transaksi berdasarkan prinsip syariah yang diperbolehkan oleh hukum Islam. Fintech peer-to-peer lending menurut Fatwa Dewan Syariah Nasional Majelis Ulama Indonesia Nomor 117/DSN-MUI/II/2018 dibolehkan dengan syarat sesuai dengan prinsip Syariah. Ketentuan prinsip Syariah yang dimaksud adalah 1) terhindar dari riba, gharar 
(ketidakpastian), maysir (spekulasi), tadlis (menyembunyikan cacat), dharar (merugikan pihak lain), dan haram; 2) Akad baku memenuhi prinsip keseimbangan, keadilan, dan kewajaran sesuai syariah dan peraturan perundang-undangan yang berlaku; 3) Akad yang digunakan selaras dengan karakteristik layanan pembiayaan seperti albai', ijarah, mudharabah, musyarakah, wakalah bi al ujrah, dan qardh;4) Terdapat bukti transaksi yaitu berupa sertifikat elektronik dan harus divalidasi oleh pengguna melalui tanda tangan elektronik yang sah; 5) Transaksi harus menjelaskan ketentuan bagi hasil yang sesuai dengan syariah; 6) penyelenggara layanan boleh mengenakan biaya (ujrah) dengan prinsip ijarah. Subyek hukum dalam fintech peer-to-peer lending ada tiga pihak, yaitu penyelenggara, penerima pembiayaan, dan pemberi pembiayaan (Baihaqi, 2018).

\section{Service Excellent}

Pelayanan atau service adalah kegiatan atau manfaat yang dapat diberikan suatu pihak kepada pihak lainnya yang pada dasarnya tidak berwujud dan tidak pula berakibat pemilikan sesuatu dan produksinya dapat atau tidak dapat dikaitkan dengan suatu produk. Malayu dalam Helena 2012. Pelayanan dapat juga diartikan setiap tindakan membantu, menolong, memudahkan, menyenangkan, dan manfaat bagi orang lain. Pelayanan nasabah adalah rangkaian kegiatan sikap dan perilaku petugas bank dalam menerima kehadiran atau berkomunikasi dengan nasabah secara langsung maupun tak langsung. Buchari Alam dalam Helena. 2012 (Fitria, 2012).

Dalam kegiatan pelayanan dikenal istilah pelayanan prima yang artinya adalah kepedulian kepada pelanggan dengan memberikan layanan terbaik untuk memfasilitaskan kemudahan pemenuhan kebutuhan, sebagai usaha untuk mencapai kepuasan tamu atau pelanggan. Tujuan pelayanan prima adalah memberikan pelayanan yang dapat memenuhi dan memuaskan pelanggan atau masyarakat serta memberikan fokus pelayanan kepada pelanggan. Untuk dapat memberikan pelayanan prima dan menjalin hubungan yang baik dengan para pelanggan maka yang menjadi kunci keberhasilannya adalah orang (human), karena pelayanan dapat menjalin hubungan dengan pelanggan yang merupakan interaksi antara pekerja, perusahaan dengan masyarakat di luar perusahaan. Pengembangan pelayanan prima merupakan bagian dari upaya perusahaan untuk

SERVICE EXCELLENT BAGI FINTECH SYARIAH 
memberikan pembekalan kepada pelayanan dalam mengantisipasi tuntutan kebutuhan pelayanan profesional. Pelayanan prima memberikan kesan pertama sampai akhir dalam melayani tamu. Dengan adanya sistem tersebut dapat digunakan oleh semua pihak dalam pengambilan suatu keputusan maupun mempermudah kegiatan operasional suatu perusahaan tersebut (Apriliawati \& Suminar, 2017).

Layanan yang diberikan dengan berfokus kepada kepuasan pengguna sering disebut juga dengan layanan prima atau layanan istimewa (service excellent). Esensi dalam layanan prima adalah upaya memberikan layanan terbaik bagi pelanggan yang berorientasi pada kepentingan pelanggan/pengguna sehingga memungkinkan kita mampu memberikan kepuasan yang optimal. Upaya memberikan layanan yang terbaik ini dapat diwujudkan apabila kita dapat menonjolkan kemampuan, sikap, penampilan, perhatian, tindakan dan tanggung jawab yang baik dan terkoordinasi. Service excellent adalah dua kata berasal dari bahasa inggris service dan excellent. Service artinya jasa, pelayanan, tugas dan excellent artinya unggul, ulung, baik sekali, dengan demikian dalam perspektif ini pelayanan yang sempurna merupakan salah satu nilai jual yang penting bagi sebuah industri jasa. Sebuah pelayanan dikatakan sempurna apabila dampak yang terjadi pada konsumen adalah loyalitas yang sangat tinggi. Sehingga konsumen tidak akan ragu-ragu lagi untuk membeli produk yang dihasilkan oleh perusahaan tersebut. Bahkan, pelanggan yang loyal akan dengan sendirinya memasarkan produk atau jasa yang ditawarkan oleh perusahaan kepada konsumen lain dengan sukarela dikarenakan sudah sangat nyaman dan di untungkan dengan adanya pelayanan yang sempurna tersebut. (Zein Bastiar, 2010).

Dalam pemasaran jasa kualitas pelayanan merupakan hal yang dipertimbangkan para konsumen. Pada prinsipnya, definisi kualitas jasa berfokus pada upaya pemenuhan kebutuhan dan keinginan konsumen serta ketepatan penyampaiannya untuk mengimbangi harapan konsumen (Sari, Wibowo, and Gitasiswhara dalam Rosi Rismayanti 2016) Perusahaan dituntut untuk dapat melampaui harapan pelanggan dengan memberikan pelayanan terbaik. Melampaui harapan pelanggan bukan hal mudah. Diperlukan usaha atau strategi agar perusahaan mampu memenuhi harapan. Karena semua perusahaan berlomba memberikan pelayanan untuk 
menciptakan budaya perusahaan yang terbaik dimata konsumen serta merekrut dan melatih SDM agar mempunyai karakter karyawan sesuai dengan kebutuhan perusahaan. Memberikan kualitas pelayanan melalui salah satu proses yaitu dengan memberikan nilai tambah sehingga harapan pelanggan dapat terlampaui. Pemberi jasa akan dinilai oleh pelanggan seberapa professional dalam melayani konsumen, disinilah service excellence sangat diperlukan. Jasa atau pelayanan adalah salah satu faktor yang mempengaruhi kepuasan konsumen. Bagaimanapun konsumen ingin mendapatkan pelayanan yang terbaik dari penyedia jasa. Memberikan kualitas melalui pelayanan yang prima akan positif yang memberikan andil dalam pelanggan kepuasan ketika itu dikelola tepat (Rismayanti \& Hurriyati, 2017).

Sebelum melakukan penelitian, peneliti berusaha menelaah literatur karya ilmiah sebelumnya yang berkaitan dengan judul yang diteliti. Hasil penelitian-penelitian yang pernah dilakukan sebelumnya perlu dikemukakan sebagai bahan perbandingan dengan penelitian yang dilakukan penulis. Adapun karya-karya ilmiah yang relevan dengan topik yang peneliti angkat antara lain:

Aam Slamet Rusydiana, dalam penelitiannya yang berjudul Bagaimana Mengembangkan Industri Fintech Syariah di Indonesia? Pendekatan Interpretive Structural Model (ISM), menyebutkan bahwa Sebagai negara dengan populasi penduduk muslim terbesar di dunia, prospek fintech syariah di Indonesia sangat baik. Studi ini mencoba menjawab masalah yang terjadi, strategi, dan pemangku kepentingan yang terlibat dalam pengembangan fintech syariah di Indonesia menggunakan pendekatan Interpretive Structural Model (ISM). Masalah inti yang dihadapi dalam pengembangan industri teknologi keuangan syariah adalah kurangnya instrumen kebijakan yang menjaga proses kerja fintech dan ketersediaan sumber daya manusia untuk fintech. Strategi atau fondasi inti yang diperlukan dalam kerangka pengembangan fintech syariah adalah kemampuan untuk mengelola dan menganalisis data di era big data dan sumber daya manusia dalam pemasaran digital. Untuk aspek ekosistem atau aktor yang terlibat dalam pengembangan fintech syariah di Indonesia, aktor pentingnya, antara lain pemerintah atau regulator, lembaga pendidikan (universitas), dan juga industri yang ada (bank dan lembaga keuangan lainnya) (Rusydiana, 2019).

SERVICE EXCELLENT BAGI FINTECH SYARIAH 
Penelitian yang dilakukan Achmad Basori Alwi yang berjudul Pembiayaan Berbasis Teknologi Informasi (Fintech) yang Berdasarkan Syariah, menyimpulkan bahwa Layanan Pembiayaan Berbasis Teknologi Informasi Berdasarkan prinsip syariah merupakan meminjam uang penyelenggaraan layanan jasa keuangan untuk mempertemukan pemberi pinjaman (pembiayaan) dengan penerima pinjaman dalam rangka melakukan perjanjian pinjam meminjam dalam mata uang rupiah secara langsung melalui sistem elektronik dengan menggunakan jaringan internet. Sesuai dengan pengertian tersebut pihak yang menjadi subjek hukum adalah pemberi pembiayaan, penyelenggara layanan serta penerima pembiayaan. Kegiatan usaha dalam rangka penyaluran pembiayaan dilakukan berdasarkan prinsip-prinsip dan ketentuan syariah serta dalam penyelenggarannya dilakukan pengaturan dan pengawasan secara terintegrasi oleh Otoritas Jasa Keuangan. Pembiayaan melalui Layanan Pembiayaan Berbasis Teknologi Informasi Berdasarkan prinsip syariah membingkai hubungan hukum antara para subjek hukumnya dengan akad-akad yang sesuai syariah. Akad yang mengakomodir hubungan hokum para pihak dan di gunakan oleh mayoritas penyelenggara Layanan Pembiayaan Berbasis Teknologi Informasi Berdasarkan prinsip syariah adalah akad Alqardh, Wakalah bil Ujrah serta Musyarakah. Penerapan akad-akad syariah yang dilakukan oleh penyelenggara layanan pembiayaan wajib memberikan jaminan kepatuhan syariah serta perlindungan bagi pengguna layanan pembiayaan (Alwi, 2018).

M. Zainul Wathani dan Afiati Kurniasih dalam penelitiannya yang berjudul Konsep Service Excellent Perbankan Syariah Berdasarkan AlQur'an Concept Of Islamic Banking Service Excellent By The Qur'an menyebutkan bahwa Konsep service excellence yang diterapkan di perbankan syariah saat ini memiliki kaitan yang sangat erat dengan konsep service excellence yang ada dalam Al-Qur'an. Perbankan syariah dalam memberikan pelayanan telah menerapkan banyak nilainilai yang terkandung dalam Al-Qur'an seperti bersikap lemah lembut kepada nasabah, memastikan kehalalan produk yang dijual, memaafkan nasabah dan sebagainya. Akan tetapi dalam memberikan pelayanan ada beberapa hal yang perlu diperhatikan oleh perbankan syariah yaitu bank syariah tidak boleh membedakan pelayanan antara 
nasabah prima dan nasabah biasa, serta bank syariah harus memberikan niat tulus ikhlas karena Allah, karena pelayanan yang terkesan baik tidak akan dianggap amal shaleh apabila tidak diniatkan secara ikhlas kepada Allah SWT. Perbankan syariah telah mengimplementasikan banyak nilai-nilai konsep service excellence yang terdapat di dalam Al-Qur'an, hal ini disebabkan karena banyaknya kesamaan antara konsep service excellence perbankan syariah saat ini dengan konsep service excellent yang terdapat dalam AlQur'an. Implementasi konsep service excellent Al-Qur'an pada pelayanan perbankan syariah misalnya berdo'a bersama sebelum memulai pekerjaan, berusaha memastikan kehalalan produk yang dijual, adanya SOP yang melarang bersentuhan tangan dengan nasabah yang bukan muhrim dan sebagainya (Wathani \& Kurniasih, 2015).

Muhammad Nizar dan Badrus Soleh dalam penelitiannya yang berjudul Pengaruh Pelayanan Prima (Service Excellent) Terhadap Kepuasan Nasabah menjelaskan bahwa Hasil penelitian menunjukkan bahwa variabel pelayanan prima yang terdiri dari Kemampuan (X1), Sikap (X2), Penampilan (X3), Perhatian (X4), Tindakan (X5), Tanggung jawab (X6) dan variabel bebas kepuasan yang terdiri dari kualitas produk (X7), kualitas pelayanan (X8), biaya dan kemudahan (X9) secara simultan mempunyai pengaruh yang signifikan terhadap yaitu variabel kepuasan nasabah $(\mathrm{Y})$. Hal ini ditunjukkan dengan hasil perhitungan $\mathrm{F}$ hitung $\geq F$ tabel $(57,120 \geq 0,362)$ atau Sig F $\leq 5 \%(0,000 \leq 0,05)$. Sedangkan besarnya kontribusi variabel pelayanan prima yang terdiri dari Kemampuan (X1), Sikap (X2), Penampilan (X3), Perhatian (X4), Tindakan (X5), Tanggung jawab (X6), dan variabel bebas kepuasan yang terdiri kualitas produk (X7), kualitas pelayanan (X8), biaya dan kemudahan (X9) terhadap variabel kepuasan nasabah (Y) ditunjukkan dengan nilai koefisien determinannya sebesar 0,070 atau $70 \%$ sedangkan sisanya sebesar 30\% dipengaruhi oleh variabel lain di luar variabel penelitian ini. 2. Hasil penelitian menunjukkan bahwa variabel pelayanan prima yang terdiri dari Kemampuan (X1), Sikap (X2), Penampilan (X3), Perhatian (X4), Tindakan (X5), Tanggung jawab (X6), dan variabel bebas kepuasan yang terdiri dari kualitas produk (X7), kualitas pelayanan (X8), biaya dan kemudahan (X9) secara parsial hanya Kemampuan (X1), Penampilan (X3), Tindakan (X5), kualitas pelayanan $(X 8)$, biaya na kemudahan (X9) yang mempunyai pengaruh signifikan terhadap kepuasan pelanggan (Y) (Nizar \& Soleh, 2017).

SERVICE EXCELLENT BAGI FINTECH SYARIAH

26

DI TENGAH KONDISI COVID-19

Trimulato, Asyraf Mustamin, dan Ismawati 


\section{METODE PENELITIAN}

Jenis penelitian yang digunakan dalam tulisan ini adalah dengan menggunakan studi pustaka yang diperoleh dari beberapa sumber. Sumber yang dianggap relevan dengan tema penelitian yaitu terkait dengan Fintech syariah dan layanan prima (service excellent).

Penelitian ini bersifat kualitatif yaitu menggambarkan suatu subyek penelitian. Dalam hal ini adalah perkembangan fintech syariah khususnya jenis fintech Peer To Peer Landing Syariah. Kemudian tentang pola layanan prima (service excellent) di tengah wabah covid-19.

Jenis data yang digunakan dalam tulisan ini adalah data kualitatif yang bersumber dari data sekunder. Data yang telah disajikan sebelumnya oleh lembaga tertentu, dan data tersebut dianggap relevan dengan tema. Data-data yang digunakan penulis antara lain: Teori-teori yang peneliti ambil dari berbagai literatur. Pengambilan data-data dari hasil yang telah tersaji dari suatu lembaga, seperti data yang dikeluarkan oleh Otoritas Jasa Keuangan tentang fintech syariah. Serta dari berbagai sumber yang dianggap sesuai. Penelusuran melalui buku, artikel, jurnal, majalah, internet dan sumber lainnya.

Batasan dalam tulisan ini difokuskan pada produk keuangan syariah yaitu lembaga fintech syariah lebih khusus lagi tentang fintech peer to peer landing syariah. Kemudian bentuk layanan prima yang perlu dilakukan lembaga fintech syariah di tengah wabah covid-19.

Teknik pengumpulan data yang diperlukan dalam tulisan ini adalah dengan menggunakan beberapa metode yaitu: Studi Kepustakaan Metode ini digunakan untuk menggali dasar-dasar teori yang terkait dengan lembaga fintech syariah dan terkait dengan layanan prima (service excellent). Kemudian Pengamatan Setiap data yang didapatkan dari berbagai sumber diamati dan dianalisa terkait dengan perkembangan fintech syariah. Data yang dikeluarkan oleh Otoritas Jasa Keuangan yang kemudian diolah oleh penulis. Kemudian tentang konsep service excellent bagi lembaga fintech syariah.

Metode analisis data yang digunakan adalah dengan menggunakan pendekatan kualitatif deskriptif yaitu dengan cara memaparkan metode teori tentang fintech syariah dan service excellent. Data yang diperoleh akan dioleh oleh penulis dan akan menguraikan 
dari data tersebut. Kemudian akan diuraikan tentang pola service excellent bagi fintech syariah di tengah wabah covid-19.

\section{HASIL DAN PEMBAHASAN}

\section{Perkembangan Fintech Syariah}

\section{Tabel 1}

Lembaga Fintech Peer To Peer Landing Syariah Periode April 2020

\begin{tabular}{|c|l|c|c|c|}
\hline No & \multicolumn{1}{|c|}{ Komponen } & Desember 2019 & April 2020 & Pertumbuhan \\
\hline 1 & Aset & $50,618,571,149$ & $50,591,727,786$ & $-0.05 \%$ \\
\hline 2 & Pelaku Fintech & 164 & 161 & $-1,83$ \\
\hline 3 & $\begin{array}{l}\text { Fintech Syariah } \\
\text { Terdaftar }\end{array}$ & 11 & 11 & 0 \\
\hline 4 & $\begin{array}{l}\text { Fintech Syariah } \\
\text { Berizin }\end{array}$ & 1 & 1 & 0 \\
\hline
\end{tabular}

Sumber: Otoritas Jasa Keuangan Fintech Lending Periode April 2020 (Data diolah)

Dari data diatas menunjukkan kondisi dari fintech lending syariah pada periode desember 2019 sampai dengan april 2020. Menunjukkan dari sisi asset mengalami penurunan sebesar $-0,05$ persen. Begitupun dengan pelaku fintech secara umum yang juga mengalami penurunan sebanyak $-1,83$ persen. Adapun jumlah fintech syariah berjumlah 12 perusahaan atau hanya 7,45persen dari total keseluruhan. Terdiri dari 11 berstatus terdaftar dan 1 perusahaan berstatus berizin. Secara perkembangan jumlah fintech lending syariah belum bertambah. Total aset fintech lending keseluruhan pada periode april sebesar $3,614,528,740,453$, dan fintech lending syariah berkontribusi sebesar $50,591,727,786$ atau hanya sebesar 1,40 persen. Data ini menunjukkan bahwa fintech lending syariah yang terbilang baru masih belum tumbuh secara baik, dan kemudian juga masih memberi kontribusi yang terbilang kecil dari total fintech secara keseluruhan. Dalam kondisi seperti ini fintech syariah perlu didorong untuk dapat tumbuh, dan berkompetisi dengan fintech yang telah ada sebelumnya, dan tetap menjaga prinsip syariah. Pertumbuhan fintech lending syariah yang belum maksimal membuka peluang untuk fintech syariah dapat tumbuh lebih baik kedepannya, khususnya untuk menawarkan produk-produk yang menarik kepada masyarakat. Sehingga masyarakat dapat memenuhi keuangannya tanpa melanggar aturan prinsip syariah. Dengan demikian fintech syariah akan dapat berkontribusi lebih besar bagi perekonomian kedepannya. Adapun 12 perusahaan fintech syariah yang terdaftar/berizin yaitu; 
1. PT Ammana Fintek Syariah

2. PT Dana Syariah Indonesia

3. PT Danakoo Mitra Artha

4. PT Alami Fintek Sharia

5. PT Syarfi Teknologi Finansial

6. PT Duha Madani Syariah

7. PT Qazwa Mitra Hasanah

8. PT Maslahat Indonesia Mandiri

9. $\quad$ PT Ethis Fintek Indonesia

10. PT Kapital Boost Indonesia

11. PT Piranti Alphabet Perkasa

12. PT Berkah Finteck Syariah

Dari 12 perusahaan fintech syariah, beberapa diantaranya ada yang fokus pada layanan penyaluran pembiayaan pada segmen mikro, dan ada pada segmen property (Perumahan) dan segmen pada biro haji dan umroh. Ada 5 perusahaan fintech syariah yang fokus pada penyaluran pembiayaan UMKM yaitu PT. Berkah Finteck Syariah, PT. Qazwa, PT. Kapital Boost, PT. Alami Sharia, dan PT. Ammana.

\section{Service Excellent Bagi Lembaga Fintech Syariah di Tengah Wabah Cobid-19}

Lembaga fintech syariah merupakan produk perkembangan lembaga keuangan syariah yang ada saat ini. Fintech syariah keberadaannya masih terbilang baru dan sedang untuk meningkatkan pemahaman masyarakat tentang produk fintech syariah, khususnya pada produk peer to peer lending (P2P) syariah. Dalam proses kegiatan dan transaksinya fintech syariah mengikuti aturan-aturan yang ada termasuk dalam hal ini aturan dari Fatwa DSN MUI yang mengatur tentang fintech syariah. Saat ini fintech syariah sedang berjalan untuk menjadi wadah bagi siapa saja yang hendak bertransaksi keuangan dengan memanfaatkan teknologi dan juga tidak bertentangan dengan prinsip Islam. Hanya saja dalam proses perjalanan ini fintech syariah juga terkena dampak dari munculnya virus corona (covid-19). Semenjak kemunculan virus ini di bulan maret 2020, pemerintah mengeluarkan beberapa kebijakan yang berkaitan dengan kondisi yang ada sampai saat ini. Di tengah wabah virus ini sangat berdampak 
terhadap kegiatan ekonomi, baik sektor riil maupun sektor keuangan, tanpa terkecuali bagi lembaga fintech syariah. Adanya intruksi terhadap untuk menjaga jarak, larangan untuk berkumpul, dan berkegiatan dari rumah, melumpuhkan banyak kegiatan ekonomi yang berdamoak pada penurunan nilai dari kegiatan ekonomi. Banyak pusat-pusat kegiatan ekonomi mengalami penurunan pendapatan, dan banyak perusahaan yang mengalami penurunan sehingga berakibat sulit melakukan pembayaran kewajiban kepada lembaga keuangan. Otoritas Jasa Keuangan telah mengeluarkan Surat Edaran terkait dengan pemberian keringanan untuk nasabah kredit/ pembiayaan di bank. Fintech syariah khususnya fintech landing syariah juga menyalurkan pembiayaan kepada nasabahnya/ konsumennya, sehingga nasabah-nasabah tersebut juga kesulitan dalam membayar kewajibannya, sehingga juga berakibat pada konsumen pendana (investor). Namun, dalam kondisi seperti ini fintech lending syariah juga harus tetap dapat bertahan, dan meningkatkan kinerjanya dengan memberikan pelayanan prima bagi para konsumennya. Dalam kondisi seperti layanan prima harus diterapkan oleh lembaga fintech syariah untuk menjaga investornya dan memberikan perhatian terhadap nasabah atau pihak penerima pembiayaan.

Dalam transaksi fintech bentuk landing syariah terdiri dari tiga pihak yaitu pihak pertama pemilik dana atau investor dan biasa disebut dengan pendana, kemudian pihak fintech syariah yang akan mengelolah dana pendana, akan disalurkan pada pembiayaan yang produktif dan menghasilkan. Kemudian pihak ketiga adalah pihak yang mengajukan pembiayaan atau pihak yang menerima pendanaan. Bentuk layanan prima yang harus diberikan oleh lembaga fintech syariah dalam kondisi covid-19, berbeda dengan layanan prima pada saat kondisi normal seperti sebelumnya. Jika biasanya segala transaksi dilakukan seutuhnya melalui layanan teknologi, saat ini sentuhan dalam bentuk perhatian kepada kedua belah konsumen/ nasabah harus lebih mendapatkan perhatian.

Bentuk layanan prima yang perlu dilakukan fintech lending syariah untuk nasabah pendana atau investor, yaitu dengan meningkatkan layanan yang telah ada sebelumnya. Seperti terus melakukan iklan dan informasi terkait fintech syariah. Dalam kondisi ekonomi yang kurang baik saat ini, mengakibatkan calon pendana atau investor merasa kurang yakin untuk menginvestasikan pada pada

SERVICE EXCELLENT BAGI FINTECH SYARIAH

$30 \mid$

DI TENGAH KONDISI COVID-19

Trimulato, Asyraf Mustamin, dan Ismawati 
suatu lembaga, mengingat risiko juga cukup besar. Maka dari itu layanan fintech syariah dibutuhkan berupa membuat programprogram yang menarik minat investor untuk menjadi pendana. Buatlah promo-promo menarik, tanpa merugikan perusahaan. Adanya pemberian hadiah atau kegiatan lainnya yang membuat para nasabah pendana mendapatkan perhatian dengan ada program yang menarik. Sehingga investor pendana percaya menepatkan dananya pada fintech syariah untuk membiayai proyek-proyek yang dapat memberi hasil maksimal. Fintech syariah perlu menawarkan produk-produk yang memberi akses kemudahan dan dibutuhkan di tengah wabah ini.

Bentuk layanan prima yang perlu dilakukan fintech lending syariah bagi nasabah penerima dana atau pembiayaan. Menjaga hubungan baik dengan nasabah pembiayaan yang ada sebelumnya. Jangan memutuskan hubungan dengan nasabah pembiayaan berikan perhatian yang lebih agar tetap mampu bertahan untuk memenuhi kewajibannya. Bentuk layanan prima bagi nasabah pembiayaan yang terkena dampak dari covid-19 berikan perhatian yang lebih jika diperlukan berikan dukungan dan dorongan agar nasabah dapat menjalankan usahanya lebih baik. Lebih jauh pihak fintech tidak sekedar menanyakan kemampuan bayarnya, melainkan ikut menasehati dan memberikan masukan bagaimana usaha nasabah pendana dapat tetap berjalan dengan baik. Jika ingin lebih baik pihak fintech dapat memberikan layanan promosi atau ikut memasarkan produk-produk nasabah pendananya. Fintech syariah punya websait yang dapat menjadi market place bagi nasabah pendananya, dalam websait itu mengenalkan dan memasarkan produk nasabahnya. Kemudian layanan prima lain yang dapat diberikan ikut memberikan keringan pembayaran bagi nasabah penerima pendanaan yang terkena dampak virus, yang mengakibatkan benar-benar tidak mampu. Serta layanan prima lainnya yang dapat dilakukan lembaga fintech lending syariah di tengah wabah covid-19 ini adalah memberikan santuan sosial bagi nasabah ataupun non nasabah yang terkena dampak, kegiatan bersifat sosial. Layanan ini dapat dilakukan sendiri ataupun dengan bekerjasama dengan pihak lain.

\section{E. KESIMPULAN}


Perkembangan fintech syariah (fintech landing) saat ini masih belum maksimal, jumlah fintech syariah masih minim jika dibandingkan fintech secara keseluruhan. Total aset fintech syariah sebesar 50,591,727,786 atau sebesar 1,4 persen dari total asset fintech seluruhnya. Pada periode april 2020 aset fintech syariah mengalami penurunan sebesar 0,05 persen. Adapun jumlah perusahaan fintech baru 12 perusahaan atau sebesar 7,45 persen dari total keseluruhan perusahaan fintech sebanyak 161 perusahaan. Pada periode april 2020 jumlah pelaku fintech mengalami penurunan sebesar 1,83 persen. Jumlah fintech 2019 sebanyak 164 sampai dengan periode april jumlah fintech lending sebanyak 161 perusahaan.

Service excellent bagi lembaga fintech syariah di tengah wabah covid-19 perlu tetap dijaga, dan berbeda layanan ketika wabah ini belum ada. Bentuk layanan prima fintech lending syariah yaitu bagi investor atau pihak pendana maka fintech perlu melakukan penawaran produk yang menarik. Membuat promosi-promosi yang meningkatkan minat investor untuk tetap menyimpan dananya atau menjadi pendana pada fintech syariah. Bentuk layanan prima bagi pihak nasabah/ konsumen yang didanai yaitu dengan meningkatkan silaturahim, dan meningkatkan perhatian kepada nasabah penerima dana. Berikan keringan pembayaran bagi nasabah yang terkena dampak, berikan layanan yang dapat membantu pemasaran produk nasabah dengan memfaatkan teknologi atau website yang dimiliki, dan meningkatkan layanan yang bersifat sosial. Kegiatan sosial baik dari perusahaan fintech syariah sendiri ataupun bekerjasama dengan pihak lain.

\section{DAFTAR PUSTAKA}

Alwi, A. B. (2018). Pembiayaan Berbasis Teknologi Informasi (Fintech) yang Berdasarkan Syariah. Al-Qanun: Jurnal Pemikiran Dan Pembaharuan Hukum Islam. https://doi.org/10.15642/alqanun.2018.21.2.255-271

Ansori, M. (2019). Perkembangan dan Dampak Financial Technology (Fintech) terhadap Industri Keuangan Syariah di Jawa Tengah. Wahana Islamika: Jurnal Studi Keislaman.

Apriliawati, M., \& Suminar, R. (2017). Pelayanan Prima Pada Orang Tua Siswa di Sempoa SIP TC Paramount Summarecon. Sekretari.

Baihaqi, J. (2018). Financial Technology Peer-To-Peer Lending Berbasis Syariah di Indonesia. Tawazun: Journal of Sharia Economic Law.

\section{SERVICE EXCELLENT BAGI FINTECH SYARIAH}


Fahlefi, R. (2018). Inklusi Keuangan Syariah Melalui Inovasi Fintech Di Sektor Filantropi. In Batusangkar International Conference III (pp. 205-212). Batusangkar International Conference III, October 15-16, 2018.

Fintech, T. G. (2017). Kajian Bisnis Fintech Syariah. Telkom Digital Services. https://doi.org/10.1111/j.1365-2966.2008.13419.x

Fitria, H. (2012). Strategi Servis (Pelayanan Prima) Bank Syariah Terhadap Nasabah Non-Muslim (Studi Kasus Pada Bpr Syariah Amanah Ummah). Al Infaq, 3(1), 58-95.

Hiyanti, H., Nugroho, L., Sukmadilaga, C., \& Fitrijanti, T. (2020). Peluang dan Tantangan Fintech (Financial Technology) Syariah di Indonesia. Jurnal Ilmiah Ekonomi Islam. https://doi.org/10.29040/jiei.v5i3.578

Muchlis, R. (2018). Analisis SWOT Financial Technology (Fintech) Pembiayaan Perbankan Syariah Di Indonesia (Studi Kasus 4 Bank Syariah Di Kota Medan). AT-TAWASSUTH: Jurnal Ekonomi Islam. https://doi.org/10.30821/ajei.v1i1.2735

Mukhlisin, M. (2020). FinTech Syariah di Indonesia dan Pandemi Covid. https://sharianews.com. https://sharianews.com/posts/fintechsyariah-di-indonesia-dan-pandemi-covid-19

Nizar, M., \& Soleh, B. (2017). Pengaruh Pelayanan Prima (Service Excellent) Terhadap Kepuasan Nasabah. Jurnal Ekonomi Islam, 8, 257-276.

Rismayanti, R., \& Hurriyati, R. (2017). PELAKSANAAN SERVICE EXCELLENCE BADAN USAHA BPJS KESEHATAN KCU BANDUNG. Journal of Business Management Education (JBME). https://doi.org/10.17509/jbme.v1i2.5971

Rusydiana, A. (2019). Bagaimana Mengembangkan Industri Fintech Syariah di Indonesia? Pendekatan Interpretive Structural Model (ISM). Al-Muzara'ah. https://doi.org/10.29244/jam.6.2.117-128

Sadari, \& Hakim, A. (2016). Revitalisasi Keuangan Inklusif dalam Sistem Perbankan Syariah di Era Financial Technology. Journal of Islamic Economics, Finance, and Banking.

Bastiar. Z. SERVICE EXCELLENT DALAM RANGKA MEMBENTUK LOYALITAS PELANGGAN. (2010). Manajerial. https://doi.org/10.17509/manajerial.v9i1.1211

Setyaningsih, E. D. (2018). Analisis SWOT Implementasi Financial 
Technology Syariah pada PT Telkom Indonesia. Syi ar Iqtishadi: Journal of Islamic Economics, Finance and Banking. https://doi.org/10.35448/jiec.v2i2.4386

Wathani, M. Z., \& Kurniasih, A. (2015). Konsep Service Excellence Perbankan Syariah Berdasarkan Al-Qur'an. Nisbah: Jurnal Perbankan Syariah, 1(1), 1. https://doi.org/10.30997/jn.v1i1.245

Wijaya, R. Y. (2020a). Bisnis Fintech Syariah Belum Bisa Melesat. republika.co.id. https://republika.co.id/berita/q44o79383/bisnisfintech-syariah-belum-bisa-melesat-ini-penyebabnya

Wijaya, R. Y. (2020b). Bisnis fintech syariah terganggu wabah corona. https://keuangan.kontan.co.id/. https://keuangan.kontan.co.id/news/bisnis-fintech-syariahterganggu-wabah-corona

Yarli, D. (2018). Analisis Akad Tijarah Pada Transaksi Fintech Syariah Dengan Pendekatan Maqhasid. YUDISIA: Jurnal Pemikiran Hukum Dan Hukum Islam. https://doi.org/10.21043/YUDISIA.V9I2.4766 